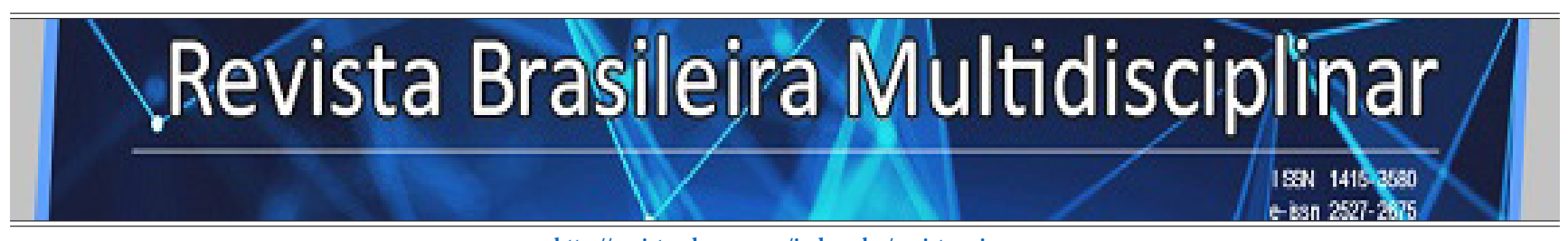

http://revistarebram.com/index.php/revistauniara

\title{
BONE AGING AND FUNCTIONAL CAPACITY OF SMOKERS
}

Anselmo Cordeiro de Souza*; Mirian Dias Moreira e Silva*; Monica Karla Vojta Miranda*; Natalice Oliveira Cerqueira*; Sabrina Clares de Almeida*; Noemi Pereira dos Santos ${ }^{\star *}$; Izabel Maria de Oliveira ${ }^{* *}$; Elias Ferreira Porto ${ }^{* * *}$.

${ }^{*}$ Master's degree in Health Promotion at the Brazil Adventist University- UNASP.

${ }^{*}$ Degree in Physiotherapy at the Brazil Adventist University- UNASP.

${ }_{* * *}$ PhD. Translational Medicine- Universidade Federal de São Paulo- UNIFESP. Master's degree in Health Promotion at the Brazil Adventist University- UNASP.

*Autor para correspondência e-mail: anselmo.vivamelhor@hotmail.com

\section{Palavras-Chave}

Capacidade Funcional

Densidade Óssea

Hábito de Fumar

\section{KEYWORDS}

Health Profile

Smoking

Body Composition

Bone Density

\begin{abstract}
Objective: Assess bone mineral content and density related to functional capacity of smokers. Method: This is a cross-sectional study of methods and procedures specific to descriptive epidemiological research and a quantitative approach. The research was carried out in a Reference Center for Rehabilitation and Health Care in the city of São Paulo. A sociodemographic questionnaire and related factors were applied, the Fagerström instrument for the assessment of nicotinic dependence and the six-minute walk test to evaluate functional capacity. Dual-energy X-Ray Radiological Absortometry was performed - from the lumbar spine, femoral neck and total femur. Results: Twenty-four smokers aged between 45 and 75 years, of both sexes, mean age of $58.6 \pm 5.9$ years, mean body mass index of $26.7 \pm 3.4$, the majority of sex female $16(66 \%)$. Degree of low prevalence of nicotine dependence. There was also a significant association between bone mass and functional capacity among smoking women. Conclusion: There was a significant association between bone mass and functional capacity among female smokers. It is desirable for health care providers in the clinical context of rehabilitation to employ systems that ensure addressing other co-occurring comorbidities, such as smoking.
\end{abstract}

\section{ENVELHECIMENTO ÓSSEO E CAPACIDADE FUNCIONAL DE TABAGISTAS}

Objetivo: avaliar o conteúdo e densidade mineral óssea relacionada a capacidade funcional de tabagistas. Método: trata-se de estudo transversal, de métodos e procedimentos próprios da pesquisa epidemiológica descritiva e de abordagem quantitativa. A pesquisa realizou-se em um Centro de Referência em Reabilitação e Assistência à Saúde no município de São Paulo. Aplicou-se um questionário sociodemográfico e fatores relacionados, o instrumento Fagerström de avaliação da dependência nicotínica e o teste de caminhada de seis minutos para avaliação da capacidade funcional. Realizou-se Absortometria Radiológica de Raio X de Dupla Energia - de coluna lombar, colo do fêmur e fêmur total. Resultados: avaliaram-se 24 tabagistas com idade entre 45 e 75 anos, de ambos os sexos, idade média de 58,6 $\pm 5,9$ anos, Índice de Massa Corporal médio de 26,7 $\pm 3,4$, a maioria do sexo feminino 16 (66\%). Grau de dependência nicotínica prevalente baixa. Houve ainda significante associação entre massa óssea e capacidade funcional entre mulheres tabagistas. Conclusão: houve significante associação entre massa óssea e capacidade funcional entre tabagistas do sexo feminino. Torna-se desejável os prestadores de cuidados de saúde no contexto clínico da reabilitação, empregar sistemas que assegurem abordar outras comorbidades coocorrentes, tais como o tabagismo. 
Souza et al.

\section{INTRODUCTION}

The smoking habit can lead the individual to its addiction, which is defined as a chronic disease characterized by dependence on nicotine present in cigarette smoke and found in other forms of tobacco use (SOUZA , 2018). There is consensus in the scientific literature on smoking as one of the main causes of death worldwide. Exposure to cigarette smoke and smoking are associated with about 6 million deaths per year (PINTO, 2015). Bone aging stands out as a phenomenon that results in morbidity and mortality in older populations, including a gradual loss in quality of life, linked to modifiable risk factors, including inadequate nutrition, physical inactivity and smoking, resulting in significant loss (CURTIS, 2015).

The bone constantly undergoes modeling and remodeling to remove an aged bone matrix and replace it with a new one preserving bone strength. Bone mass can be expressed in bone mineral content (BMC), that is, the amount of mineral in grams contained in a given bone projection, and bone mineral density (BMD), obtained by dividing the BMC by the bone area of the site, obtaining what is conventionally called density, measured in $\mathrm{g} / \mathrm{cm} 2$, that is, BMD is the concentration of bone tissue in a given volume of bone (CLARKE, 2008; LAZARETTI-CASTRO, 2004).

Bone health status has been classified as normal, osteopenia and osteoporosis (SOUZA, 2018). In osteopenia and osteoporosis, there is a decrease in BMD (RAIZS, 2005). Smoking has often been indicated as a risk factor for osteoporotic fractures (Silva et al., 2020). Osteoporosis, in turn, has health consequences with reported impairments in functional capacity (DALY, 2017).

Functional capacity (FC) can be defined as the individual's efficiency in meeting the physical demands of daily life, ranging from basic activities for an independent functional life (activities of daily living) to more complex actions of daily routine (instrumental activities of daily living) (CAMARA, 2008). Thus, this study aims to evaluate the relationship between functional capacity and bone mass of smokers in a Reference Center for Rehabilitation and Health Care located in the south zone in the city of São Paulo, so that this information can support appropriate referrals to the local clinical context.

\section{METHOD}

This article is the result of a current thematic project under the title "Frequência de Sarcopenia em Fumantes"(Frequency of Sarcopenia in Smokers), which aimed to verify the relationship between muscle and bone loss in smokers. Its methodological path includes the collection of various other data to achieve the proposed objectives, with data previously published and discussed (SILVA , 2020; SOUZA, 2018; SOUZA, 2018a). This is a non-experimental, cross-sectional investigation, carried out from November 2016 to November 2017, in a Reference Center for Rehabilitation and Health Care, located in the south zone in the city of São Paulo. Individuals who accepted the invitation to participate in the study were interviewed by one of three trained researchers, at a previously scheduled time.

Twenty-four adult smokers aged 45 to 75 years, of both sexes, having a smoking history equal to or greater than 20 packs/year participated in this investigation. The study did not include patients with severe neurological conditions, inability to walk, severe lung diseases with reduced lung function, decreased mobility due to chronic diseases that can affect physical performance, previous surgery within two months, acute myocardial infarction in the last six months prior to the study and use of systemic corticosteroids during the last six weeks.

In the first moment, the participant was informed of the details of the investigation explicit in the Informed Consent Form (ICF). Individuals who agreed to participate by signing the informed consent form were asked to complete a sociodemographic questionnaire and related factors, created by the researchers, for individual assessment, to verify the inclusion criteria, in addition to characterizing the sample and to know the profile of the study participants.

To assess nicotine dependence, the Fagerström test was used. The Fagerström evaluation method consists 
of multiple-choice questions related to personal data, education and smoking status. This questionnaire contains six questions with a maximum score equal to 10 points, and the higher the score, the greater the dependence on nicotine. It is widely used with reports of good psychometric quality (MENESES-GAYA, 2009; FERREIRA, 2009).

The degree of nicotine dependence, measured by the Fagerström test, can be classified depending on the total score of dependence as low (up to 4 points), medium ( 5 points), high ( 6 and 7 points) or very high (8 to 10 points) (MENESES-GAYA, 2009; FERREIRA, 2009).

All participants also took the six-minute walk test (6MWT) to assess the relationship between bone mass and functional capacity. The test was carried out in a corridor with a length of 30 meters and free of movement of people. Patients received prior instructions to come on the day of the test wearing comfortable clothes and shoes, in addition to maintaining their usual medication. Before taking the test, patients had a rest period of at least 10 minutes as instructed in the Brazilian standard for the six-minute walk test (BRITTO; SOUSA, 2006). Walking tests are seen as a quick and low-cost alternative to assess the impairment of functional capacity, as they may reflect the potential for carrying out activities of daily living (CAMARA, 2008).

The assessment of body and bone composition was carried out through Dual-energy X-ray absorptiometry - DXA, which allows the assessment of body composition as a whole and by body segment (lean mass, fat mass and bone mass of the trunk, upper and lower limbs), enabled through a partnership for research purposes, with a GE-LUNAR PRIMO densitometer, located at the Diagnostics Center of the Adventist Hospital of São Paulo - HASP. Using a DXA exam in the lumbar spine, femoral neck, and total femur, the BMD and BMC values were obtained.

Statistical analyzes of the data in this research were performed using the SPSS (Statistical Package of Social Science, v.22). Data are presented as mean and standard deviation, stratified by sex. The symmetry of the data was analyzed using the Shapiro-Wilk test. The comparison between groups was performed using the " $\mathrm{t}$ " test for quantitative variables. Pearson's correlation was also performed, interpreting the magnitude of the correlations in the following classification: correlation coefficients $<0.4$ (weak magnitude correlation), $>0.4$ to $<0.5$ (moderate magnitude) and $>0,5$ (strong magnitude). $\mathrm{P} \leq 0.05$ was considered statistically significant (Field, 2013). The project was submitted for evaluation by the Research Ethics Committee of the Centro Universitário Adventista de São Paulo, in compliance with the Resolution of the National Health Council no. 510/16 (Brazil, 2016), accepted under number: 1,820,836.

\section{RESULTS}

Of those who were eligible, 24 individuals completed the questionnaires, 6MWT and DEX exams, which were assessed in this investigation. Most of those evaluated in the study were female, 66\%. Regarding health condition, none of the participants used alcohol, however $58 \%$ declared to be ex-alcoholics, $45 \%$ declared to be hypertensive, $37 \%$ reported the presence of other NCDs, none declared to be diabetic. Mean age was $58.6 \pm 5.9$ years and average Body Mass Index (BMI) was $26.7 \pm 3.4$, as shown in Table 1 . 
Table 1 - Characterization of the study sample by sex on average and standard deviation.

\begin{tabular}{lc}
\hline \multicolumn{1}{c}{ Variables } & $\begin{array}{c}\text { Total } \\
(\mathbf{N}=\mathbf{2 4})\end{array}$ \\
\hline Age (years) & $58.6 \pm 5.9$ \\
Weight $(\mathbf{K g})$ & $68.9 \pm 12.1$ \\
Height $(\mathbf{m})$ & $1.60 \pm 0.11$ \\
BMI $(\mathbf{k g} / \mathbf{m} 2)$ & $26.7 \pm 3.4$ \\
\hline
\end{tabular}

BMI: Body Mass Index. ${ }^{\star} \mathrm{p} \leq 0,05$

Source: Prepared by the authors, São Paulo, 2018.

Regarding smoking, $66 \%$ smoke 11 to 20 cigarettes a day. In the sample of this study, the average score of $5.25 \pm 2$ represents a "medium" degree of nicotine dependence for the group in general. Specifically, 9 (37\%) had "weak" nicotine dependence, 4 (16\%) moderate, 8 (33\%) high and $3(12 \%)$ very high.

In the characterization and evaluation of the difference between sexes of bone mineral content and bone mineral density using the t-test, there was no significant difference between sexes for BMD in any of the segments. In the BMC, there was a significant difference in all the studied segments, according to Table 2.

Table 2 - Characterization of Bone Mineral Content and Bone Mineral Density.

\begin{tabular}{lccc}
\hline \multicolumn{1}{c}{ Variables } & Female $(\mathbf{n}=\mathbf{1 6})$ & Male $(\mathbf{n}=\mathbf{0 8})$ & p (t-test) \\
\hline Lumbar spine & & & \\
$\mathrm{BMD}\left(\mathrm{g} / \mathrm{cm}^{2}\right)$ & $1.0271 \pm 0.14$ & $1.0488 \pm 0.16$ & 0.62 \\
$\mathrm{BMC}(\mathrm{g})$ & $50.69 \pm 8.96$ & $66.79 \pm 11.77$ & ${ }^{\star} 0.001$ \\
Femoral Head & & & \\
$\mathrm{BMD}\left(\mathrm{g} / \mathrm{cm}^{2}\right)$ & $0.8607 \pm 0.15$ & $0.9070 \pm 0.09$ & 0.45 \\
$\mathrm{BMC}(\mathrm{g})$ & $3.96 \pm 0.77$ & $4.79 \pm 0.5$ & ${ }^{\star} 0.01$ \\
Total Right Femur & & & \\
$\mathrm{BMD}\left(\mathrm{g} / \mathrm{cm}^{2}\right)$ & $0.8797 \pm 0.16$ & $0.9530 \pm 0.12$ & 0.24 \\
$\mathrm{BMC}(\mathrm{g})$ & $26.37 \pm 5.67$ & $33.2 \pm 3.8$ & ${ }^{*} 0.007$ \\
\hline
\end{tabular}

BMD: Bone Mineral Density; BMC: Bone Mineral Content; ${ }^{*} \mathrm{p} \leq 0.05$.

Source: Prepared by the authors, São Paulo, 2018.

Correlating functional capacity by means of the $6 \mathrm{MWT}$ with bone mass, it was observed that the greater the $\mathrm{BMD}$, the greater the distance covered in the $6 \mathrm{MWT}$ in all evaluated segments. In relation to the BMC, the correlations were not significant in the segments evaluated, although there was a tendency towards significance in the evaluation of the total femur (Table 3). 
Table 3 - Correlation between six-minute walk test and bone mass.

\begin{tabular}{lcr}
\hline \multicolumn{1}{c}{ Variables } & r & p \\
\hline Lumbar spine & & \\
6MWT $(\mathrm{m}) \times \mathrm{BMD}\left(\mathrm{g} / \mathrm{cm}^{2}\right)$ & 0.362 & 0.161 \\
6MWT $(\mathrm{m}) \times \mathrm{BMC}(\mathrm{g})$ & 0.227 & \\
Femoral head & & ${ }^{\star} 0.047$ \\
6MWT $(\mathrm{m}) \times \mathrm{BMD}\left(\mathrm{g} / \mathrm{cm}^{2}\right)$ & 0.369 & 0.195 \\
6MWT $(\mathrm{m}) \times \mathrm{BMC}(\mathrm{g})$ & 0.198 & \\
Total Right Femur & & ${ }^{\star} 0.021$ \\
6MWT $(\mathrm{m}) \times \mathrm{BMD}\left(\mathrm{g} / \mathrm{cm}^{2}\right)$ & 0.447 & 0.087 \\
6MWT $(\mathrm{m}) \times \mathrm{BMC}(\mathrm{g})$ & 0.308 & \\
\hline
\end{tabular}

BMD: Bone Mineral Density; BMC: Bone Mineral Content; 6MWT: six-minute walk test; ${ }^{*} \mathrm{p} \leq 0.05$.

Source: Prepared by the authors, São Paulo, 2018.

$\mathrm{BMC}$ and BMD were subsequently analyzed and categorized based on median values. Elderly people with higher $\mathrm{BMC}$ and $\mathrm{BMD}$ were considered to be those who were above the median values and those with lower BMC and BMD were those below the median. The distance covered in the 6MWT was evaluated as a function of $\mathrm{BMD}$, in relation to the male gender, the differences were not significant, however there was a significant difference between the groups of smoker women in all the studied segments. Regarding the $\mathrm{BMC}$, there was a significant difference between the groups of female smokers in the femoral neck and total femur segments, and a tendency towards significance in the lumbar spine. In other words, women who had greater bone mass performed better on the 6MWT than those who had less bone mass, as shown in Figure 1. 
Figure 1 - Six-minute walk distance by female smokers according to the median bone mineral density and bone mineral content.

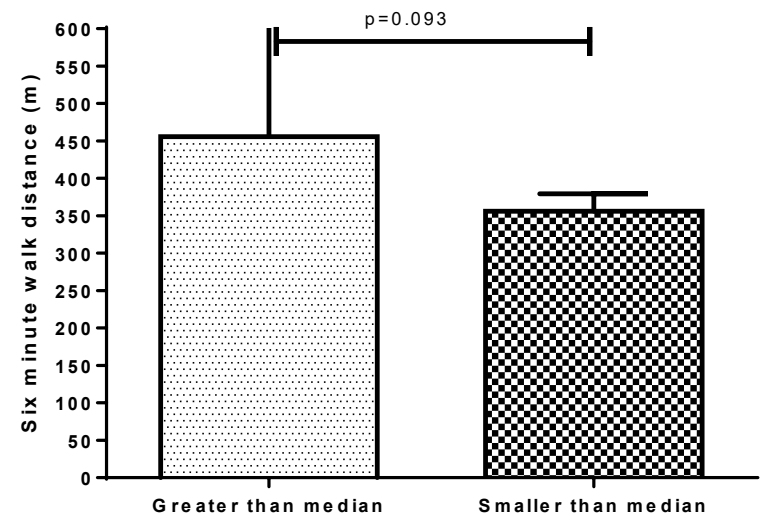

Lumbar spine - BMC

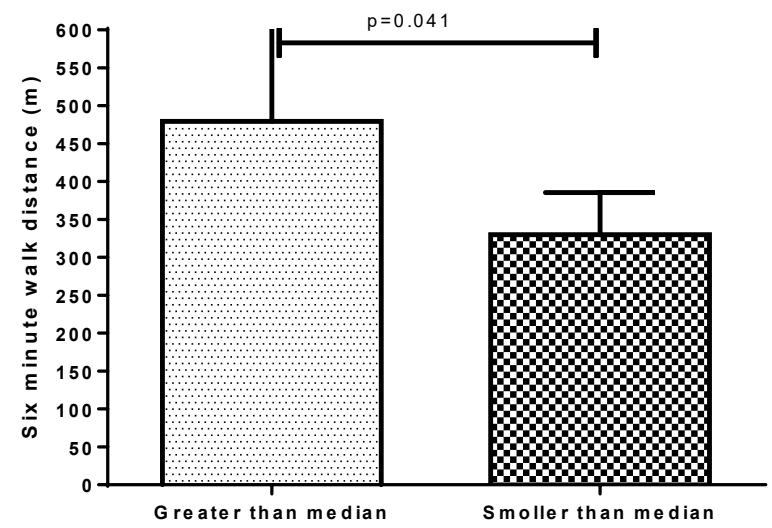

Total femur - BMC

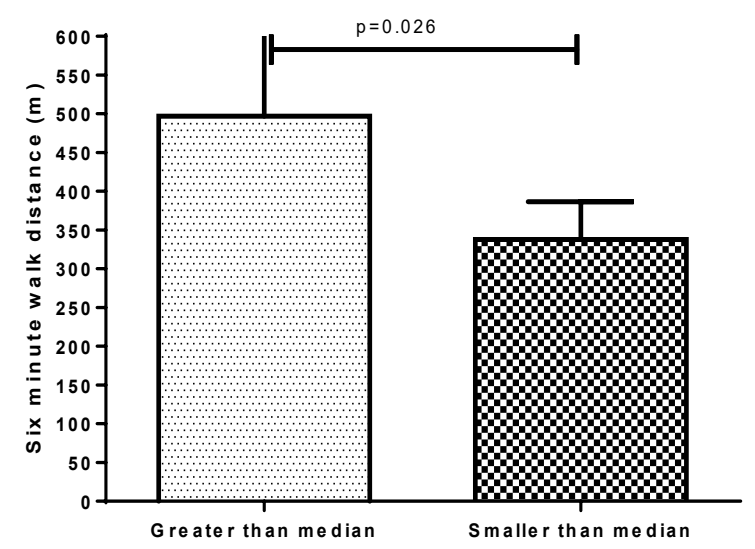

Femoral Neck - BMD

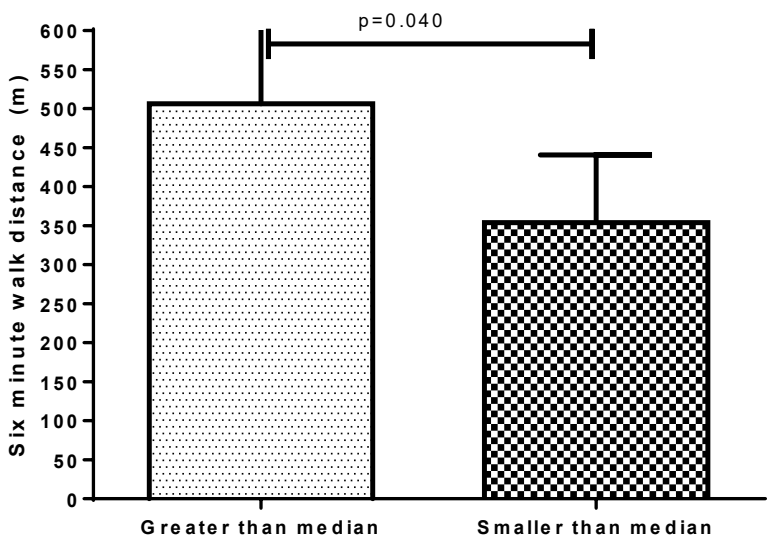

Femoral Neck - BMC

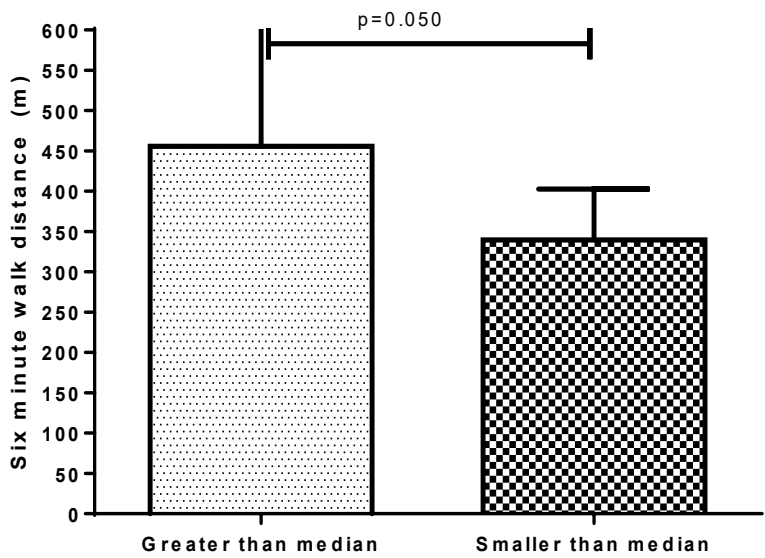

Lumbar spine - BMD

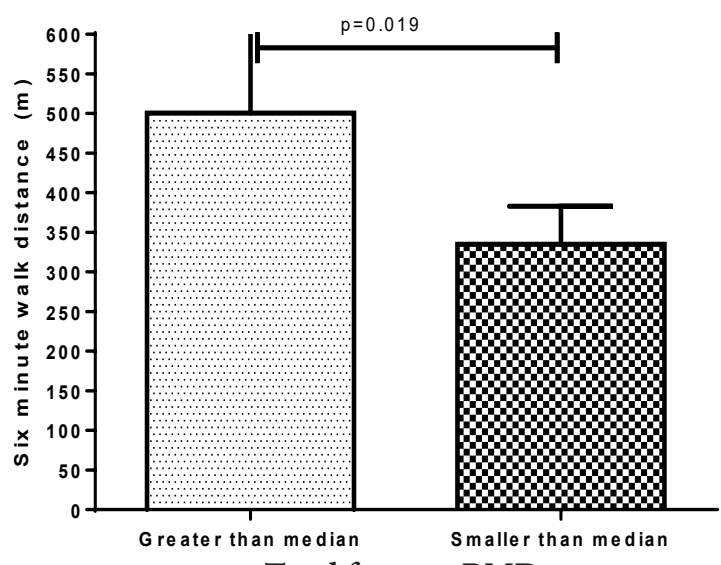

Total femur - BMD

Source: Prepared by the authors, São Paulo, 2018. 


\section{Discussion}

This investigation aimed to evaluate the relations between functional capacity and bone density of smokers in the context of a clinical sample in a Reference Center for Rehabilitation and Health Care, so that this information can support appropriate referrals according to the local reality.

It should be noted that BMD has been the most used indicator to analyze bone mass and diagnose bone health status, namely: normal, osteopenia and osteoporosis (SOUZA, 2018). However, BMC, becomes an important indicator, evaluating other aspects of bone mass and not only the morphological basis of bone loss, such as bone reduction that refers to the trabecular, endocortical and intracortical surfaces (SANTOS, 2013) .

It is noteworthy that when dealing with the topic of smoking and its relationship with BMD, an inverse relationship has been pointed out in the literature, although existing studies are still inconclusive regarding the relationships and mechanisms between smoking and possible contributions to BMD (Souza, 2018) .

Analyzing the profile of the Brazilian smoking population, Bazotti et al. (2016) and the data from the Surveillance System for Risk and Protective Factors for Chronic Diseases by Telephone Survey (VIGITEL) 2016, report that about 10\% of the Brazilian population smokes (BRASIL, 2017). These estimates were also observed in our study in the proportion of smokers in relation to the population assisted at the Reference Center for Rehabilitation and Health Care, during the period of this research.

In the present study, the female gender predominated (66\%), a profile similar to that found in the literature (CARAM, 2009; BORTOLUZZI, 2011; Campos et al., 2014) and different from the study by Oliveira et al. (2014), in which the male gender predominated. A difference that seems to be explained by the specificity of the condition of the study population, apparently more related to the male sex (OLIVEIRA, 2014).

With regard to the characteristics of this habit, in this investigation, the smoking habit of 11 to 20 cigarettes per day (66\%) was predominant, and the nicotine dependence pattern assessed by the Fagerström Test was $5.25 \pm 2.0$, representing a moderate degree of dependence, however, due to the individual score of this instrument, there was a higher proportion of individuals with "weak" dependency status.

Our results show higher proportions of osteoporosis in the population of smokers, similar to the clinical study conducted with women by Buttros and collaborators (2011), where it was identified that among smokers $35 \%$ had osteoporosis, while among nonsmokers $21 \%$ were affected by osteoporosis .

With the bone impairment of the studied segments, the performance of some motor activities, such as walking, becomes difficult, increasing the risk of falls and fractures, as well as the potential for generating disabilities. Thus, a more integrative attention is desirable given the relevance of integrated interventions and not focused on just one factor, more consistent with the complex human reality, culminating in the effective promotion of functional health.

Among the strengths of this study, the use of a gold standard instrument in the assessment of body and bone composition can be highlighted. However, data collection from only one clinical reference center and the small sample size limited the conclusions.

\section{Conclusion}

There was a significant association between bone mass and functional capacity among female smokers. It is desirable for health care providers, in the clinical context of rehabilitation, to employ systems that ensure addressing other co-existing comorbidities, such as smoking.

\section{REFERENCES}

BORTOlUZZI, M. C.; KEHRIG, R. T.; LOGUERCIO, A. D.; TRAEBERT, J. L. Prevalence and tobacco 
user profile in adult population in the South of Brazil (Joaçaba, SC). Ciência \& Saúde Coletiva, v. 16, n. 3, p. 1953-1959, 2011.

BAZOTTI, A.; FINOKIET, M.; CONTI, I. L.; FRANÇA, M. T. A.; WAQUIL, P. D. Smoking and poverty in Brazil: an analysis of the profile of the smoking population based on the 2008-09 Brazilian government Family Budget Survey. Ciência \& Saúde Coletiva, v. 21, p. 45-52, 2016.

BRASIL. Ministério da Saúde. Secretaria de Vigilância em Saúde. Departamento de Vigilância de Doenças e Agravos não Transmissíveis e Promoção da Saúde. Vigitel Brasil 2016: vigilância de fatores de risco e proteção para doenças crônicas por inquérito telefônico. Brasília: Ministério da Saúde, 2017.

BRITTO R. R.; SOUSA, L. A. P. Six Minute Walk Test - a Brazilian Standardization. Fisioterapia em Movimento, Curitiba, v.19, n.4, p. 49-54, Out-Dez., 2006.

BUTTROS, D. D. A. B.; NAHAS-NETO, J.; NAHAS, E. A. P.; CANGUSSU, L. M.; BARRAL, A. B. C. R.; KAWAKAMI, M. S. Risk factors for osteoporosis in postmenopausal women from southeast Brazilian. Revista Brasileira de Ginecologia e Obstetrícia, v. 33, n. 6, p. 295-302, 2011.

CAMPOS, T. S. Perfil de tabagistas no Centro Hiperdia Minas-Juiz de Fora. Juiz de Fora, 2014. $101 f$. Dissertação (Mestrado em Saúde) - Universidade Federal de Juiz de Fora, Juiz de Fora, 2014.

CARAM, L. M. D. O.; FERRARI, R.; TANNI, S. E.; COELHO, L. S.; GODOY, I. D.; MARTIN, R. D. S.; GODOY, I. D. Characteristics of smokers enrolled in a public smoking cessation program. Jornal Brasileiro de Pneumologia, São Paulo, v. 35, n. 10, p. 980-985, out. 2009.

CLARKE, B. Normal bone anatomy and physiology. Clinical journal of the American Society of Nephrology, v. 3, n. sup. 3, p. S131-S139, 2008.

CAMARA, F. M.; GEREZ, A. G.; MIRANDA, M. L. J.; VELARDI, M. Elderly functional capacity: types of assessment and trends. Acta fisiátrica, v. 15, n. 4, p. 249-262, 2008.

CURTIS, E.; LITWIC, A.; COOPER, C.; DENNISON, E. Determinants of muscle and bone aging. Journal of cellular physiology, v. 230, n. 11, p. 2618-2625, (2015).

DALY, R. M. Exercise and nutritional approaches to prevent frail bones, falls and fractures: an update. Climacteric, v. 20, n. 2, p. 119-124, 2017.

FERREIRA, P. L.; QUINTAL, C.; LOPES, I.; TAVEIRA, N. Test for nicotine dependence: psychometric and linguistic validation of Fagerström Test. Revista Portuguesa de Saúde Pública. v. 27, n. 2, p. 37 $56,2009$.

FIELD, A. Discovering statistics using IBM SPSS statistics. Sage publications, 2013.

KUMPEL, C.; CASTRO, A. A. M.; FREITAS, T. R.; SOUZA, J. S.; PORTO, E. F. Social aspects related to smoking in an elderly population attending te health family program. Revista Kairós: Gerontologia, v. 17, n. 3, p. 183-199, 2014. 
LAZARETTI-CASTRO, Marise. Why to evaluate bone mineral density in children and adolescents? J. Pediatr., v. 80, n. 6, p. 439-440, Dez. 2004.

LAW, M. R.; HACKSHAW, A. K. A meta-analysis of cigarette smoking, bone mineral density and risk of hip fracture: recognition of a major effect. BMJ, v. 315, n. 10, p. 841-846, 1997.

MENESES-GAYA, I. C. D.; ZUARDI, A. W.; LOUREIRO, S. R.; CRIPPA, J. A. D. S. Psychometric properties of the Fagerström test for nicotine dependence. Jornal Brasileiro de Pneumologia, v. 35, n. 1, p. 73-82, 2009.

OMS. ORGANIZAÇÃO MUNDIAL DE SAÚDE. Classificação Estatística Internacional de Doenças. São Paulo: EDUSP, 2008.

OLIVEIRA, R. M.; SANTOS, J. L. F.; FUREGATO, A. R. F. Sociodemographic profile of smokers admitted to the psychiatric ward of a general hospital. Revista Brasileira de Enfermagem, v. 67, n. 3, 2014.

PINTO, M. T.; PICHON-RIVIERE, A.; BARDACH, A. The burden of smoking-related diseases in Brazil: mortality, morbidity and costs. Cadernos de Saúde Pública, v. 31, n. 6, p. 1283-1297, 2015.

RAISZ, L. G. Pathogenesis of osteoporosis: concepts, conflicts, and prospects. The Journal of clinical investigation, v. 115, n. 12, p. 3318-3325, 2005.

SANTOS, V. R.; CHRISTOFARO, D. G. D.; GOMES, I. C.; CODOGNO, J. S.; SANTOS, L. L.; JÚNIOR, I. F. F. Association between bone mass and functional capacity among elderly people aged 80 years and over. Revista Brasileira de Ortopedia, v. 48, n. 6, p. 512-518, 2013.

SILVA, M. D. M.; OLIVEIRA, I. M.; SOUZA, A. C.; PASQUALINOTO, S. R. V.; BRITO, J. D. Q.; KUMPEL, C. Relações entre tabagismo, fatores associados e densidade mineral óssea em mulheres de meia-idade. Brazilian Journal of Development, v. 6, n. 7, p. 42499-42512, 2020.

SOUZA, A.C.; MIGUEL, A. S.; OLIVEIRA, I. M.; ACEVEDO, M. C. L.; PORTES L. A.; PORTO, E. F.; Perfil da composição corporal e densidade mineral óssea de tabagistas em um centro de referência em reabilitação e assistência à saúde. Lifestyle Journal, v. 5, n. 1, p. 20-40, 2018.

SOUZA, A. C. Relações entre tabagismo e estilo de vida na saúde óssea: revisão integrativa e estudo transversal. São Paulo, 2018. Dissertação (Mestrado Profissional em Promoção da Saúde) - Centro Universitário Adventista de São Paulo, São Paulo, 2018. 